\title{
STUDY OF CLADDING TOUGHNESS IN A PRESSURE VESSEL STEEL WATER REACTOR
}

\section{P. Soulat and M. Al Mundheri}

Commissariat à l'Energie Atomique, Centre d'Etudes Nucleaires de Saclay, Service de Recherches Métallurgiques Appliquées, France

\section{ABSTRACT}

Toughness of cladding and pressure vessel steel were determined at different temperatures in order to appreciate the participation of cladding resistance against crack propagation. The toughness of cladding is comparable with typical results on austenitic welds. The test on covered CT specimens shows the possibility of having a relatively good prevision of the behaviour of a

coated structure.

KEYWORDS

Cladding, pressure vessel steel, fracture mechanics.

INTRODUCTION

The purpose of this study is to obtain data which permits appreciation of the participation of cladding in resisting to the propagation of a surface crack in a pressure vessel steel.

in a pressure have determined the toughness of cladding and pressure steel for For that, we have determined the the ductile to brittle transition curve, in temperatures in the lower part of the ductile to britele transition curve, order to examine the influence of cladding on the start of unstablading to propagation by cleavage with covered specimens having different cladding to dition due to irradiation embrittlement.

MATERIALS IDENTIFICATION

The cladding was deposited on A 508 cl 3 steel forging of $220 \mathrm{~mm}$ thickness. It was applied by automatic submerged arc welding with strip electrode. It was constitued by three layers, the first in $24 \mathrm{Cr}-12 \mathrm{Ni}$ austenitic weld and the two others in $20 \mathrm{Cr}-10 \mathrm{Ni}$ austenitic weld. After welding a stress relief treatment was carried out at $615^{\circ} \mathrm{C}$ during $7 \mathrm{~h}$.

TOUGHNESS OF THE VESSEL STEEL

In order to determine $\mathrm{K}_{1 \mathrm{C}}$, we have employed $2 \mathrm{~T}, \mathrm{CT}$ specimens of $30 \mathrm{~mm}$ thickness. The tests were made at two temperatures, $-90^{\circ} \mathrm{C}$ and $-60^{\circ} \mathrm{C}$. All specimens exhibited branched crack, therefore the toughness values were probably at the upper band of the dispersion. 
The results are presented in table 1 . At $-90^{\circ} \mathrm{C}$ there are on the lower shelf toughness of $110 \mathrm{MPa} \sqrt{\mathrm{m}}$ and at $-60^{\circ} \mathrm{C}$ there are in the transition zone a

TABLE 1 Toughness of A 508 c1 3

\begin{tabular}{ccrrrr}
\hline $\begin{array}{c}\text { Test } \\
\text { temperature } \\
{ }^{\circ} \mathrm{C}\end{array}$ & $\mathrm{a} / \mathrm{W}$ & $\begin{array}{c}\mathrm{P} \max \\
\mathrm{N}\end{array}$ & $\begin{array}{r}\mathrm{K}_{1 \mathrm{C}} \\
\mathrm{MPa} \sqrt{\mathrm{m}}\end{array}$ & $\begin{array}{c}\mathrm{J} \\
\mathrm{KN} / \mathrm{m}\end{array}$ & $\begin{array}{c}\mathrm{K}_{\mathrm{j}} \\
\mathrm{MPa} \sqrt{\mathrm{m}}\end{array}$ \\
\hline-90 & 0.518 & 31050 & 33 & 5.6 & 33.5 \\
-60 & 0.559 & 93600 & 114 & 64.7 & 114 \\
-60 & 0.512 & 103500 & 108 & 62.6 & 112 \\
-60 & 0.530 & 111000 & 122 & & \\
\hline
\end{tabular}

TOUGHNESS OF THE CLADDING

The toughness of the cladding was determined with different kind of tests static three points precrack Charpy V testing, J- $\Delta a$ resistance curve with

The bend specimens have a section of 20 by $20 \mathrm{~mm}$, including a cladding of 8 mas of the austenitic $\left(-90^{\circ} \mathrm{C}-25^{\circ} \mathrm{C}\right.$ and $\left.20^{\circ} \mathrm{C}\right)$ by $\Delta$ a curves were determined at three temperatures specimens. The rod loaing method with multiple crease of For the

corresponding to a stable crack growth of $1 \mathrm{~mm}$ :

$$
\mathrm{J}_{\Delta \mathrm{a} 1}=\mathrm{J}_{1 \mathrm{C}}+(\mathrm{dJ} / \mathrm{da}) \times 1
$$

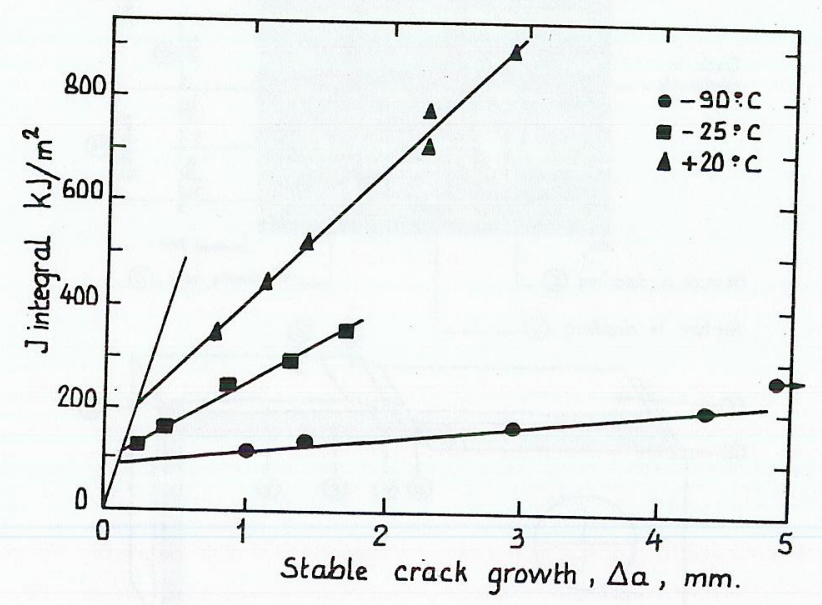

Fig. 1. J- $\Delta$ a curves of cladding at differents temperatures
The interest of this value is to release a part of uncertainties of $\mathrm{J}_{1 \mathrm{c}}$ determination interest take into account an important parameter, the slope value. The figure 2 shows the evolution of $J_{1 C}$ and $J$ with the temperature. We observe figure 2 shows the evolution of $\mathrm{J}_{1 \mathrm{C}}$ and $\mathrm{J}_{\Delta \mathrm{al}}$ with the therature. We observe an evolution of $\triangle \mathrm{al}$ more important but also more regular $-60^{\circ} \mathrm{C}$ required for other tests.

Now, if we compare $\mathrm{J}_{\triangle \mathrm{al}}$ with Charpy $\mathrm{V}$ results (Fig. 3), a good correlation can be obtained by following expression

$\mathrm{J}_{\Delta \mathrm{al}}\left(\mathrm{kJ} / \mathrm{m}^{2}\right)=9.1 \mathrm{KCV}\left(\mathrm{J} / \mathrm{cm}^{2}\right)-64$

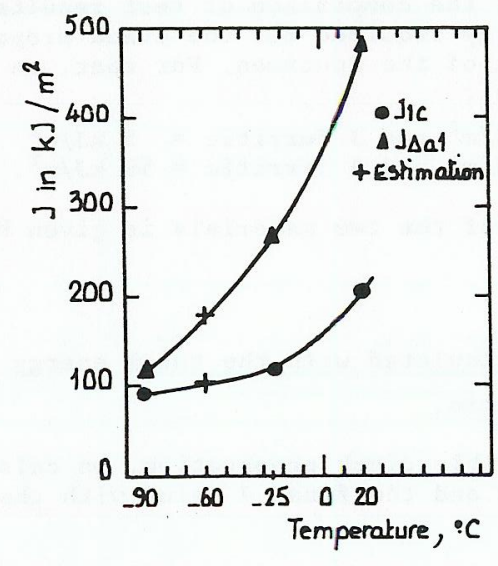

Fig. 2. Evolution of $\mathrm{J}_{1 \mathrm{C}}$ and $\mathrm{J}_{\triangle \mathrm{a} 1}$ with temperature

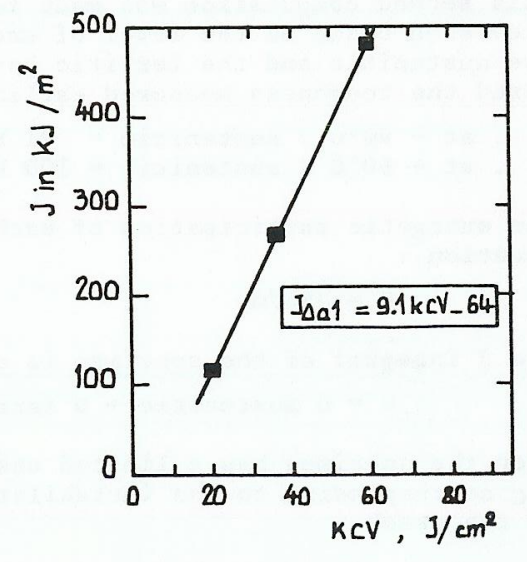

Fig. 3. Correlation between $J$ and the charpy $V$ energy
General results of toughness summarized in the table 2, show the evolution of toughness with temperature, which is most pronounced in the case of $\mathrm{K}_{\mathrm{jd}}$ determined with precrack Charpy $v$.

TABLE 2 Toughness of Cladding

\begin{tabular}{ccccccc}
\hline $\begin{array}{c}\text { Test } \\
\text { temperature } \\
{ }^{\circ} \mathrm{C}\end{array}$ & $\begin{array}{c}\mathrm{J}_{1 \mathrm{C}} \\
\mathrm{kJ} / \mathrm{m}^{2}\end{array}$ & $\begin{array}{c}\mathrm{dJ} / \mathrm{da} \\
\mathrm{MPa}\end{array}$ & $\begin{array}{c}\mathrm{J}_{\triangle \mathrm{a} 1} \\
\mathrm{~kJ} / \mathrm{m}^{2}\end{array}$ & $\begin{array}{c}\mathrm{KCV} \\
\mathrm{J} / \mathrm{cm}^{2}\end{array}$ & $\begin{array}{c}\mathrm{K}_{\mathrm{jd}} \\
\mathrm{MPa} \sqrt{\mathrm{m}}\end{array}$ & $\begin{array}{c}\mathrm{K}_{\mathrm{j}} \\
\mathrm{MPa} \sqrt{\mathrm{m}}\end{array}$ \\
\hline-90 & 91 & $25 \%$ & 116 & 20 & 104 & 131 \\
-60 & $100 \%$ & $80 \%$ & $180 \%$ & & 115 & \\
-25 & 117 & 150 & 267 & 37 & 180 & 149 \\
+20 & 212 & 268 & 480 & 60 & 237 & 200 \\
\hline
\end{tabular}

$\because$ Estimation 
TOUGHNESS OF COVERED SPECIMENS

We have employed covered $2 \mathrm{~T}$, CT specimens of 25 and $40 \mathrm{~mm}$ thickness, with $n$ cladding of 7 to $8 \mathrm{~mm}$, in order to obtain different ratios of cladding to bast metal. After precracking, specimens were broken at $-90^{\circ} \mathrm{C}$ and $-60^{\circ} \mathrm{C}$. The com putation of the stress intensity factor $\mathrm{K}$ was made in two ways, one directly $\mathrm{J}$ :

$$
\mathrm{J}=\frac{\alpha}{B} \mathrm{U}
$$

with $\alpha$ correction coefficient of MERKLE and CORTTEN, and $U$ total spent energy This a prevision based on the level of energy required for the crack propatation (the specimen. For that, we have consis dered the toughness measured earlier

$$
\begin{aligned}
& \text { at }-90^{\circ} \mathrm{C} \mathrm{J} \text { austenitic }=91 \mathrm{~kJ} / \mathrm{m}^{2} \text { and } \mathrm{J} \text { ferritic }=5 \mathrm{~kJ} / \mathrm{m}^{2} \\
& \text { at }-60^{\circ} \mathrm{C} \mathrm{J} \text { austenitic }=100 \mathrm{~kJ} / \mathrm{m}^{2} \text { and }
\end{aligned}
$$

The energetic participation of each of the two materials is given by the equation :

$$
\mathrm{U}=\mathrm{JBb} / \alpha \text {. }
$$

The $J$ integral of the specimen is calculated with the total energy :

$$
\mathrm{U}=\mathrm{U} \text { austenitic }+\mathrm{U} \text { ferritic. }
$$

When the specimen has a limited unstable crack propagation, we calculate the $\mathrm{K}_{1 \mathrm{C}}$ corresponding to the instability and the final $\mathrm{J}$ value with the new len

The results are summarized in table 3 . If we make comparison between experimental and calculated values of $\mathrm{KJ}_{\mathrm{J}}$, we notice a good agreement at - $90^{\circ} \mathrm{C}$ at $-60^{\circ} \mathrm{C}$ for $\mathrm{CI}$ specimens of $25 \mathrm{~mm}$ thickness. With CT specimens of $40 \mathrm{C}$ and thickness at $-60^{\circ} \mathrm{C}$ the experimental values are slighty lower, but in mu

\begin{tabular}{|c|c|c|c|c|c|c|c|c|c|c|}
\hline \multirow{2}{*}{$\begin{array}{l}\text { Total } \\
\text { thick. } \\
\text { mm }\end{array}$} & \multirow{2}{*}{$\begin{array}{l}\text { Cladding } \\
\text { thick. } \\
\text { mim }\end{array}$} & \multirow{2}{*}{$\begin{array}{l}\text { Temp. } \\
\text { test } \\
{ }^{\circ} \mathrm{C}\end{array}$} & \multirow{2}{*}{$\begin{array}{c}\text { Maximal } \\
\text { load } \\
\text { daN }\end{array}$} & \multirow{2}{*}{$\begin{array}{c}\mathrm{K}_{\mathrm{Q}} \\
\mathrm{MPa} \text { 晌 }\end{array}$} & \multicolumn{2}{|c|}{ Measured values } & \multirow{2}{*}{$\begin{array}{l}\text { Austenite } \\
\text { energy } \\
\text { Joules }\end{array}$} & \multirow{2}{*}{$\begin{array}{l}\text { Ferrite } \\
\text { energy } \\
\text { Joules }\end{array}$} & \multicolumn{2}{|c|}{ Calculated values } \\
\hline & & & & & $\begin{array}{l}J_{1} \mathrm{C} \\
\mathrm{KN} / \mathrm{m}\end{array}$ & $\begin{array}{l}\mathrm{K}_{\mathrm{j}} \\
\mathrm{MPa} \sqrt{\mathrm{m}} \\
\end{array}$ & & & $\begin{array}{c}\mathrm{Jc}_{\mathrm{c}} \\
\mathrm{kN} / \mathrm{m}\end{array}$ & $\frac{\mathrm{Kc}}{\mathrm{MPa} \sqrt{\mathrm{m}}}$ \\
\hline 25 & 8.4 & -90 & $\begin{array}{l}\begin{array}{l}3210 \%: \\
6 \\
6\end{array} 390\end{array}$ & 38.5 & 39 & 86 & 15.5 & 1.7 & 34 & 80 \\
\hline 25 & 8.2 & -60 & 7380 & & 68 & 117 & 16.2 & 6.3 & 72 & 120 \\
\hline 25 & 8.2 & -60 & 8280 & & 99 & 141 & 16.1 & 6.6 & 72 & 120 \\
\hline 40 & 7.3 & -60 & 9300 & 91 & 40 & 94 & 13.9 & 30.5 & 66 & 115 \\
\hline 40 & 6.7 & -60 & $\begin{array}{l}\begin{array}{l}4 \\
890:: \\
8940\end{array}\end{array}$ & $\begin{array}{l}40 \\
88\end{array}$ & 35 & 88 & 12.7 & 30.9 & 65 & 114 \\
\hline
\end{tabular}
case the fracture is more plane (Fig. 4) and the Klo of the ferritic this is probably a little lower than that with

TABLE 3 Toughness of Covered Specimens

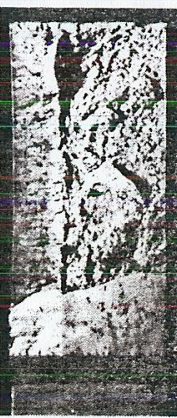

GR4

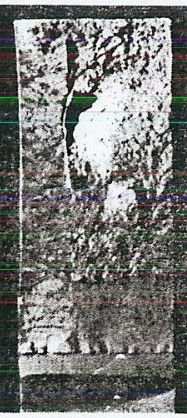

GR6

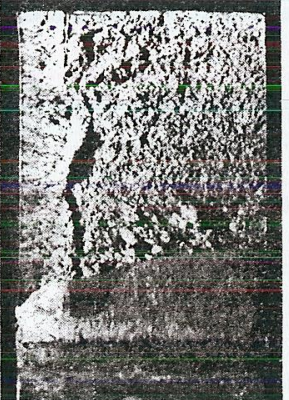

GR1

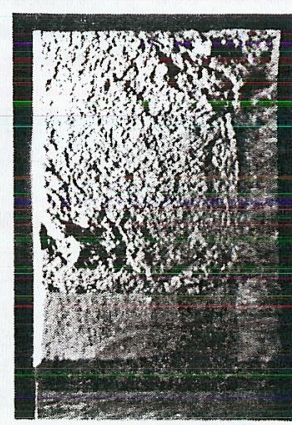

GR3
Fig. 4. Covered specimens tested at $-60^{\circ} \mathrm{C}$

EXAMINATION OF COVERED SPECIMEN TESTED AT - $90^{\circ} \mathrm{C}$

In order to have an idea of the mechanism of rupture we have made a detailed oxamination of the covered specimen of $25 \mathrm{~mm}$ thickness tested at $-90^{\circ} \mathrm{C}$. A general view of the specimen (Fig. 5) shows the different zones and in particular, the unstable crack propagation in the ferritic zone and crack in martensite at the interface between austenitic and ferritic materials.

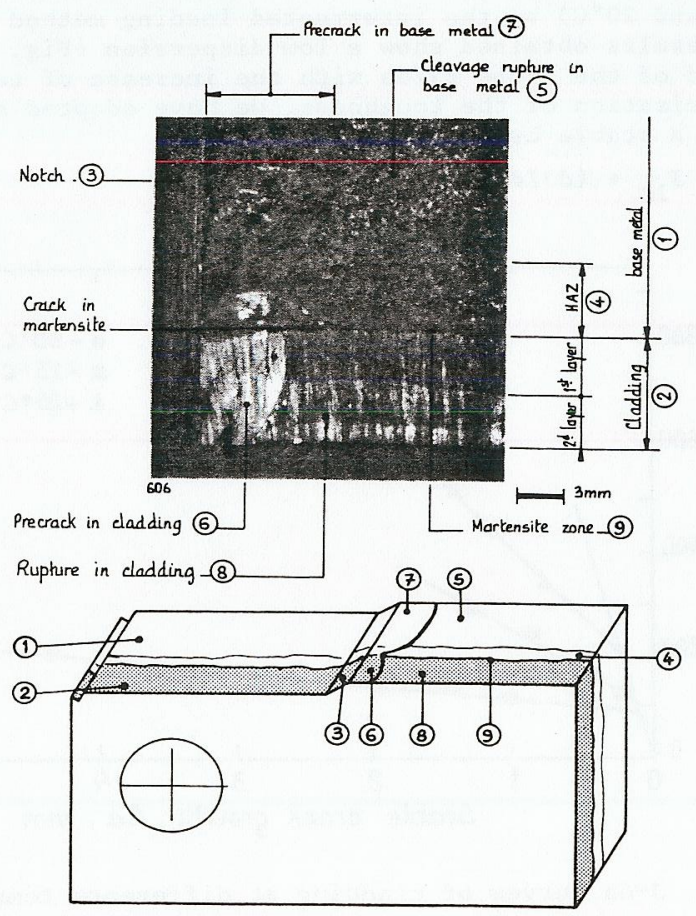

Fig. 5. Covered CT specimen tested at $-90^{\circ} \mathrm{C}$ 
Optical microscopy examination show a heat affected zone of fine grain extending over $8 \mathrm{~mm}$. This finer structure corresponds normally with a higher toughness. This is apparent for the heat affected zone and base metal appearances of rupture (Fig. 6).

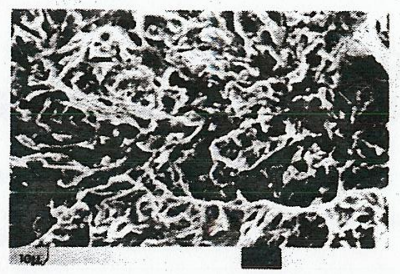

a. Examination

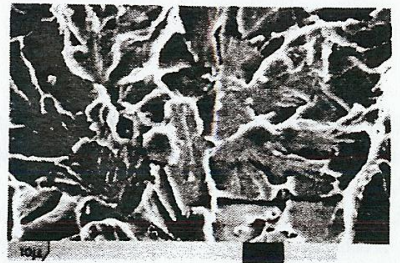

b. EXaMination OF FRACTURE SURFACE in BASE META

Fig. 6. Covered CT specimen

Evolution of fracture appearance

in the ferritic material

In the narrow martensitic zone, we observe cleavage in the plates of marter site (Fig. 7) and a crack at the interface. Examination of the cross sectlin (Fig. 8) shows that the crack has a limited depth, $1 \mathrm{~mm}$. The formation of this crack occurs during the rupture of the specimen since no crack was observed by destructive examination of regions not located at the vicinity of the fractured surfaces and observations conducted at higher test tempe ratures did not reveal the presence of such cracks. Residual stresses are suspected to contribute to the crack formation together with the loading stresses but the respective contribution were not evaluated.
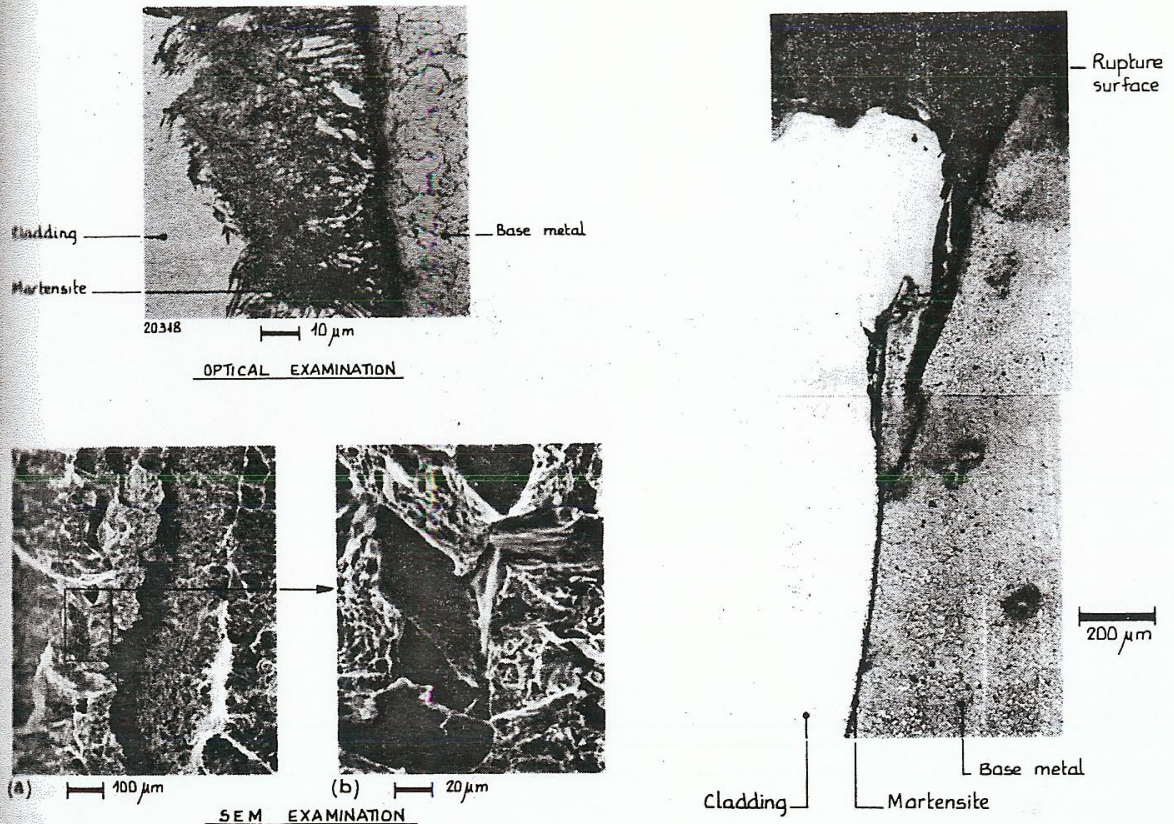

Fig. 7. Examination of the interface cladding-base metal

Fig. 8. Crack at the interface

CONCLUSION

his study allows us to draw out several conclusions :

At the low temperature investigation, the toughness of the cladding is not very high, but comparable with other results of austenitic welding.

The evolution of $\mathrm{J}_{1 \mathrm{C}}$ and the slope $\mathrm{dJ} / \mathrm{da}$ with the temperature is important. A good correlation between $\mathrm{J}_{\triangle \mathrm{al}}$ and Charpy $\mathrm{V}$ energy results, seems to behold, however more data are needed to substantiate the proposed relation ship.

The test on covered CT specimens shows the possibility of having a relatively good prevision of the behaviour of a covered structure, with the knowledge of the toughness of the components.

In tests at low temperature $\left(-90^{\circ} \mathrm{C}\right)$, some cracks were observed at the interface between cladding and base metal, cracks were induced by the rupture of the specimen, but residual stresses are suspected to contribute to reach the critical conditions for crack formation at the interface.

\section{ACKNOWLEDGEMENT}

This work is performed through a joint research effort involving Westinghouse, commissariat à l'Energie Atomique, Electricité de France and Framatome. 